\title{
Scoliid Wasps of Florida, Campsomeris, Scolia and Trielis spp. (Insecta: Hymenoptera: Scoliidae) 1
}

\author{
E. E. Grissell ${ }^{2}$
}

\section{Introduction}

The family Scoliidae is composed of fairly large, stout-bodied wasps, often brightly patterned in shades of red and yellow, white, or one of these colors in combination with black. These wasps are parasitoids of soil-inhabiting scarab beetle larvae.

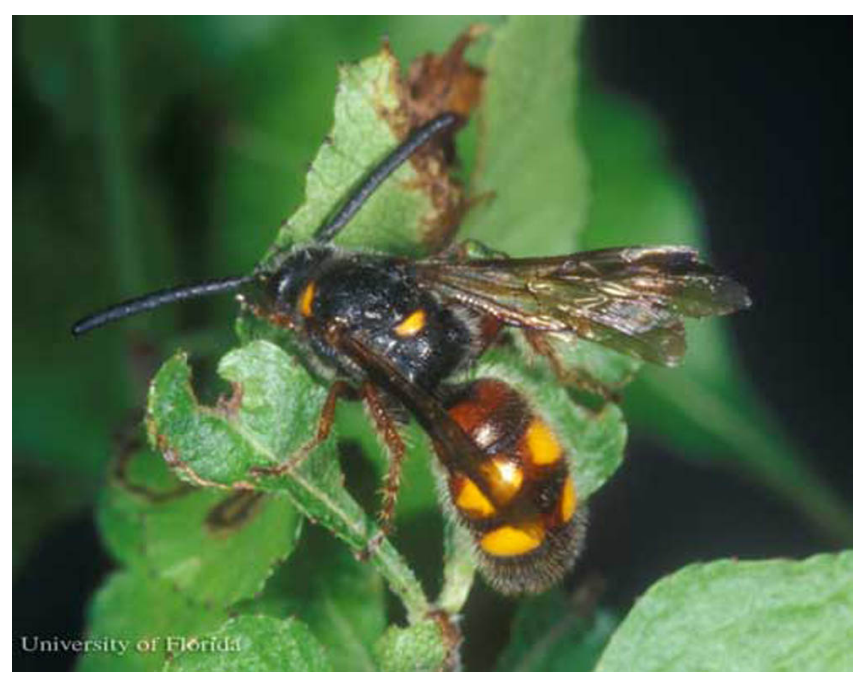

Figure 1. Adult Scolia nobilitata Fabricius, a scoliid wasp. Credits: Lyle J. Buss, University of Florida
The family Scoliidae is represented in America north of Mexico by 20 species and numerous subspecies, in five genera: Campsomeris, Crioscolia, Scolia, Trielis and Triscolia (Krombein 1951, 1958, 1967; Betrem 1972). Arnett (2000) identifies two other species in this family that are "introduced; probably not established."

The scoliid wasps and related families (e.g., parasitic tiphiids, velvet ants) traditionally form a higher group (superfamily) called the Scolioidea. These wasps combine at least two notable features which help place them in an interesting and pivotal position within the Hymenoptera. Firstly, they have the biological characteristics of the more primitive parasitic Hymenoptera, and secondly, they have the morphological characteristics of the more advanced "stinging" wasps.

This combination of characters leads most present day hymenopterists to place ancestral scolioid wasps (and the related bethyloid wasps) as the most primitive of the higher bees, wasps, and ants (Evans and Eberhard 1970, Malyshev 1968, Iwata 1976, Spradbery 1973). Brothers (1975: 577-578) disagreed, however, and stated that "it is not

1. This document is EENY-409 (IN745) (originally published as DPI Entomology Circulars 179 and 185), one of a series of Featured Creatures from the Entomology and Nematology Department, Florida Cooperative Extension Service, Institute of Food and Agricultural Sciences, University of Florida. Published: June 2007. This document is also available on Featured Creatures Website at http://creatures.ifas.ufl.edu. Please visit the EDIS Website at http://edis.ifas.ufl.edu.

2. E. E. Grissell, Florida Department of Agriculture and Consumer Services, Division of Plant Industry.

The Institute of Food and Agricultural Sciences (IFAS) is an Equal Opportunity Institution authorized to provide research, educational information and other services only to individuals and institutions that function with non-discrimination with respect to race, creed, color, religion, age, disability, sex, sexual orientation, marital status, national origin, political opinions or affiliations. U.S. Department of Agriculture, Cooperative Extension Service, University of Florida, IFAS, Florida A. \& M. University Cooperative Extension Program, and Boards of County Commissioners Cooperating. Larry Arrington, Dean 
appropriate" to consider a member of the Scolioidea as ancestral to the bees, wasps and ants.

\section{Synonymy}

The historical treatment of names (i.e., nomenclature) in Scoliidae is quite complicated and is not discussed in this circular but names have been brought to current status by the use of Krombein (1951, 1958, 1967), Betrem (1972), and personal communication with Drs. K.V. Krombein and A.S. Menke (Smithsonian Institution and Systematic Entomology Laboratory, USDA, United States National Museum, Washington, D.C., respectively).

\section{Biology}

Considering the size of scoliids (up to $5 \mathrm{~cm}$ long, wing span to $6 \mathrm{~cm}$ ), surprisingly little is known about their biology. A generalized account of biology is given in this section, and specific references for each species. Charmoy (1922) gave a short annotated review of scoliid life histories and Clausen (1940) later added to this.

Male scoliids are frequently seen cruising close to the ground in irregular figure eight patterns (Krombein, personal communication). A dozen or so may be skimming the soil's surface, but not be noticed until the eye becomes accustomed to their presence. According to Iwata (1976) a female will land and dig into the soil using first her mandibles and then her fore- and midlegs.

As mentioned above, scoliid larvae are external parasitoids of soil-inhabiting scarab beetle larvae. Some scoliid adults use the scarab's own burrow instead of digging a new one (Iwata 1976). When a female wasp reaches the scarab larva she stings it into paralysis, and then she either lays an egg on the venter of the host (Bradley 1945) or moves the beetle larva deeper into the soil, hollows out a small chamber around it, and lays an egg (Clausen 1940, Iwata 1976).

Clausen (1940) and Fleming (1968) have pointed out that not all larvae which are stung receive an egg, but such larvae never recover from the sting. According to Malyshev (1968) and Iwata (1976) the egg is always laid with its posterior end free of the host body. Scoliidae lay their eggs oriented vertically to the scarab body, while the closely related Tiphiidae lay their eggs oriented horizontally on the larva.

After hatching, the scoliid larva feeds on its scarab host for approximately one to two weeks and then spins an underground cocoon. According to Clausen (1940:307) most species "probably pass the winter in the mature larval stage within the cocoon."

\section{Hosts}

Scoliid wasps are parasitic upon larvae of soil-inhabiting scarab beetles. DeBach (1964) briefly reviewed the literature on these wasps for their use in the biological control of white grubs. The primary emphasis has been with grubs of sugar cane in Hawaii, the Mariana Islands, and Mauritius where control has ranged from "partially" to "completely" successful (DeBach 1964).

In the 1920s about 15,000 adults of two species of scoliid wasps, Campsomeris annulata Fabricius (=Campsomeriella) and Campsomeris marginella modesta (Smith) (=Micromeriella), were released in the northeastern United States to control the Japanese beetle (Krombein 1948). Even though these wasps were experimentally shown to parasitize this beetle, they did not become established in the United States (also see review by Fleming 1968).

\section{Identification}

\section{Key to Nearctic Genera and Species of Scoliidae}

The sexes of Scolliidae are separated as follows:

- females, antennae 12-segmented, abdomen 6-segmented

- males, antennae 13-segmented, abdomen 7 -segmented. In addition, males have the antennae noticeably longer than females and possess a retractable, 3-pronged plate at the tip of the abdomen.

\section{To Genus:}




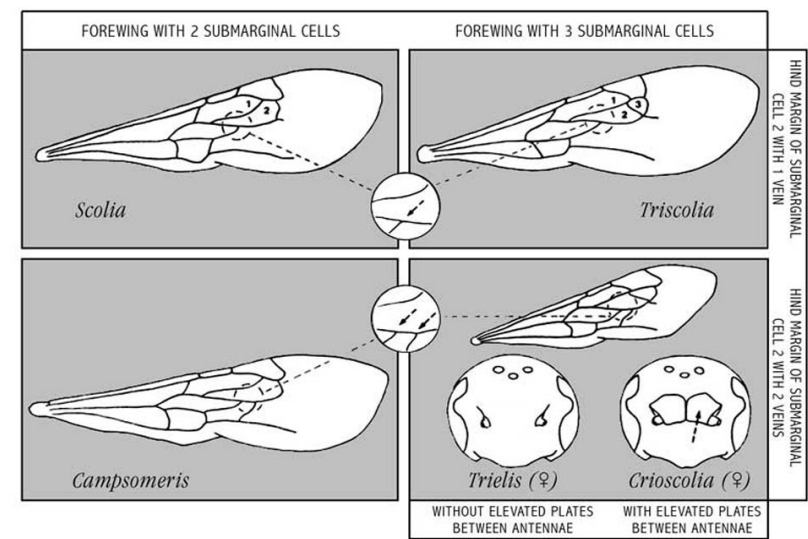

Figure 2. Key to Nearctic Genera of Scoliidae (Crioscolia and Trielis males not separable). Credits: Division of Plant Industry

\section{To Species:}

Color legend:

$\mathrm{B}=$ black

$\mathrm{O}=$ orange

$\mathrm{OB}=$ orange-brown

$\mathrm{RB}=$ red-brown

$\mathrm{W}=$ white

$\mathrm{Y}=$ yellow

\section{Species in Genus Trielis}

\section{Trielis octomaculata (Say)}

There are two Nearctic species in this genus, one of which occurs in Florida and the other in the western United States. The Florida species is $T$. octomaculata (Say) which is divided into three forms or subspecies, with T. o. hermione (Banks) occurring along the Atlantic coast into Florida.

Variation: Body length is 10 to $15 \mathrm{~mm}$. The white spots coalesce at the middle on some segments of some specimens, especially males.

\section{Species in Genus Scolia}

There are six Nearctic species, three of which occur in Florida. They may be separated by abdominal color and pattern, and the sexes are not

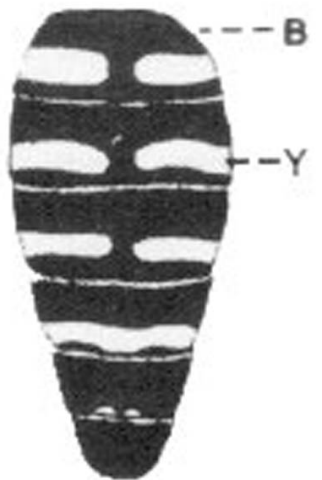

Figure 3. Trielis octomaculata (Say). Credits: Division of Plant Industry

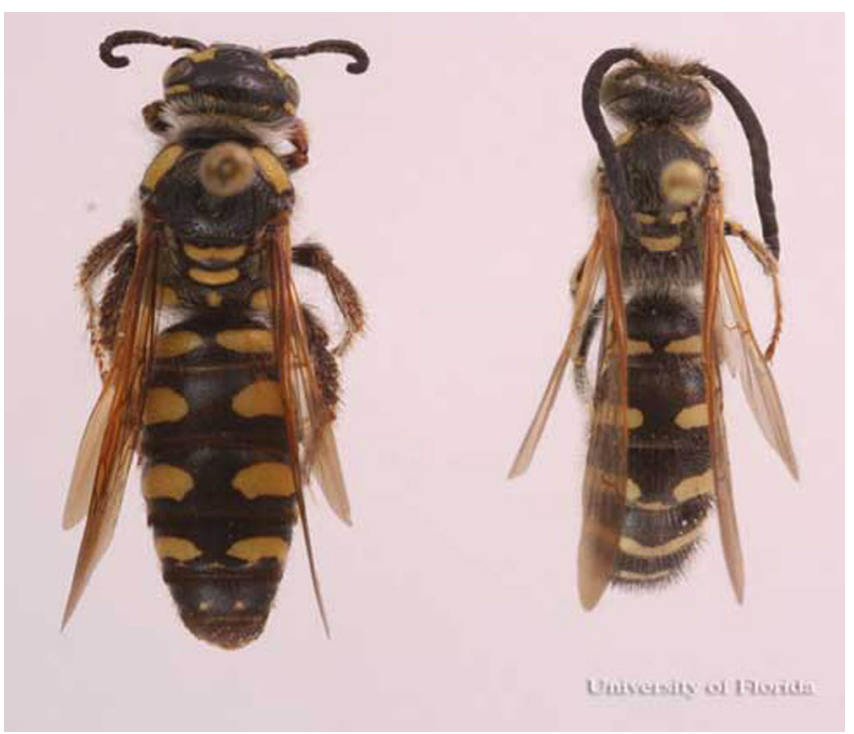

Figure 4. Adult Trielis octomaculata hermione (Banks) scoliid wasps. Female (left), male (right). Credits: Lyle J. Buss, University of Florida

noticeably different except in comparative lengths of the antennae.

\section{Scolia nobilitata Fabricius}

Variation: Body length is 10 to $15 \mathrm{~mm}$. Segment 1 rarely with faint yellow spots, and those on segments 2 and 3 are sometimes very faint. Segments 4 through 7 may be dark mahogany to black.

Distribution: This species is found from the Atlantic coast to Colorado and Arizona. Variation: The white spots coalesce at the middle on some segments of some specimens, especially males.

\section{Scolia bicincta Fabricius}




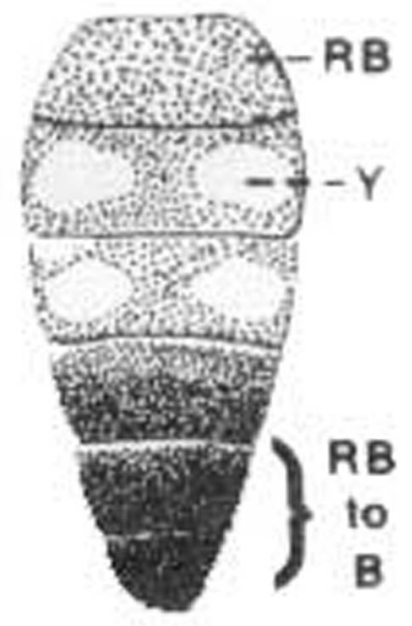

Figure 5. Scolia nobilitata Fabricius. Credits: Division of Plant Industry

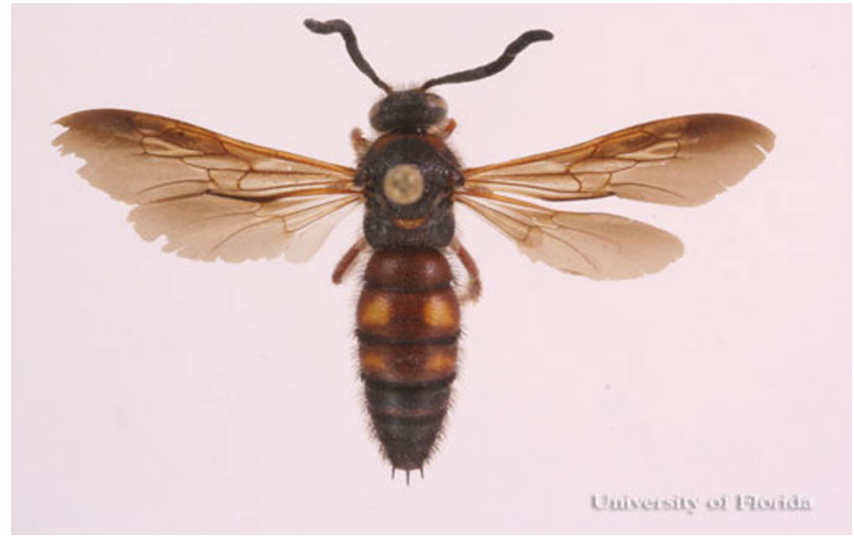

Figure 6. Adult Scolia nobilitata Fabricius, a scoliid wasp. Credits: Lyle J. Buss, University of Florida

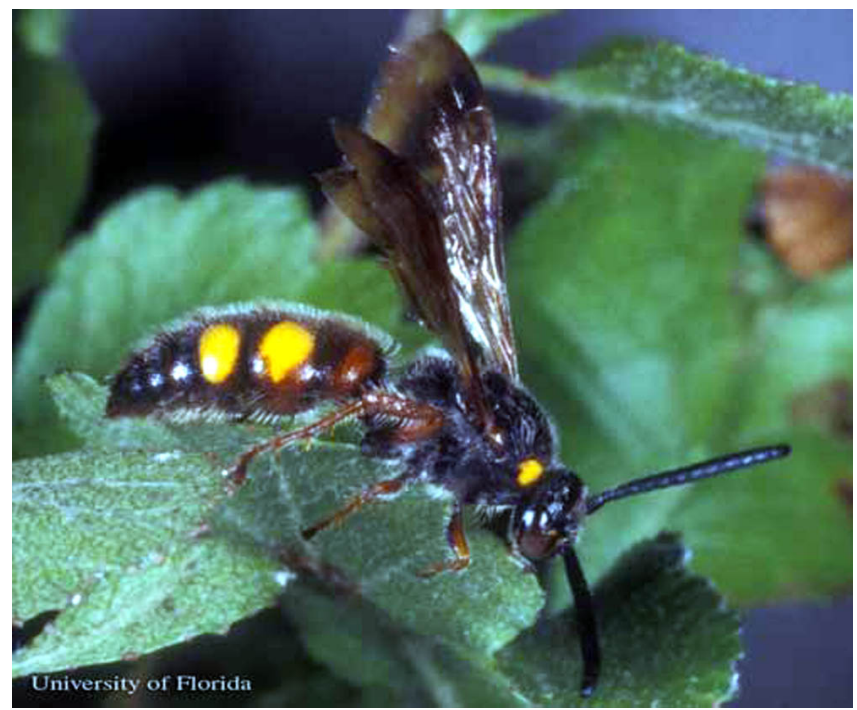

Figure 7. Adult Scolia nobilitata Fabricius, a scoliid wasp. Credits: Lyle J. Buss, University of Florida
Variation: Body length is 15 to $20 \mathrm{~mm}$. The white bands on segments 2 and 3 are sometimes broken into spots.

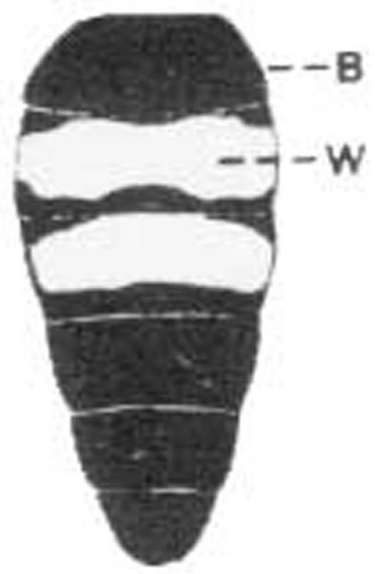

Figure 8. Scolia bicincta Fabricius. Credits: Division of Plant Industry

Distribution: This species is found throughout the eastern United States.

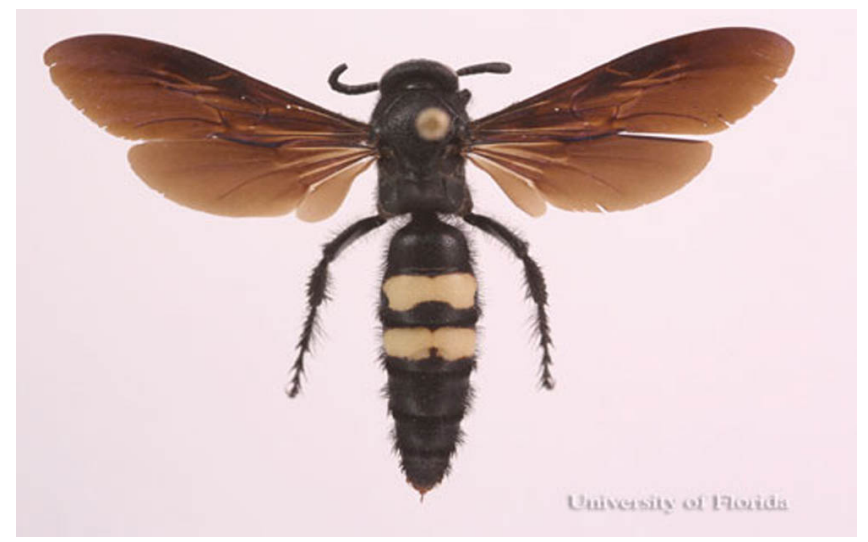

Figure 9. Adult Scolia bicincta Fabricius, a scoliid wasp. Credits: Lyle J. Buss, University of Florida

\section{Scolia dubia Say}

Variation: Body length is 20 to $25 \mathrm{~mm}$. The yellow spots on segment 3 are sometimes very faint or absent.

Distribution: This species is found throughout most of the United States.

Biology: A few observations on flight and courtship were made in 1918 by Rau and Rau and again in 1932 by Rau. 


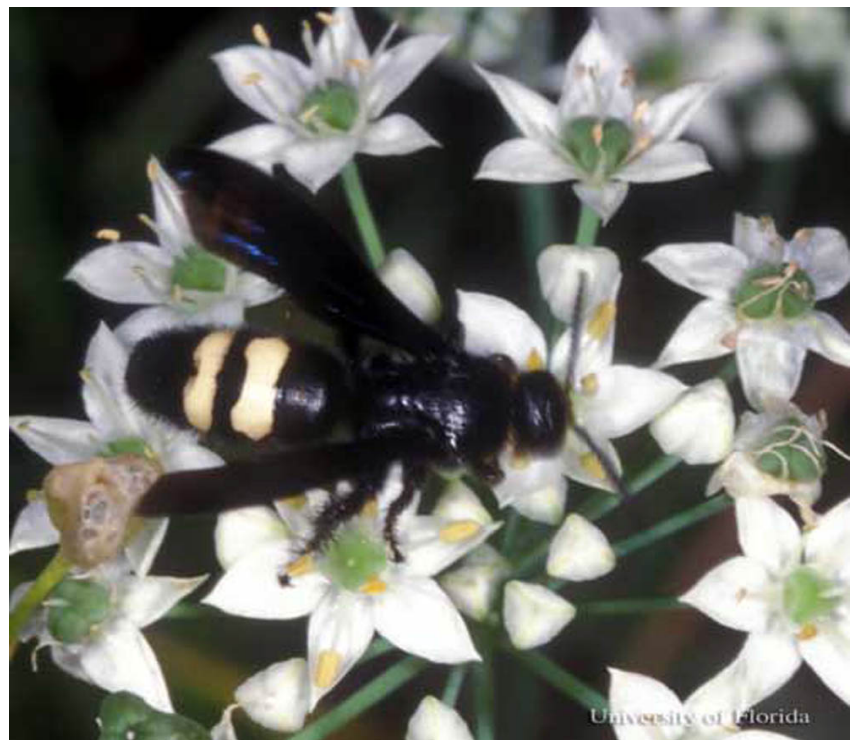

Figure 10. Adult Scolia bicincta Fabricius, a scoliid wasp. Credits: Lyle J. Buss, University of Florida

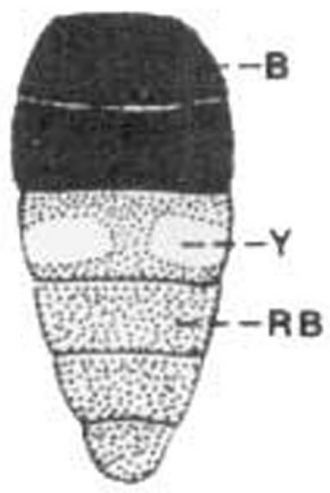

Figure 11. Scolia dubia Say. Credits: Division of Plant Industry

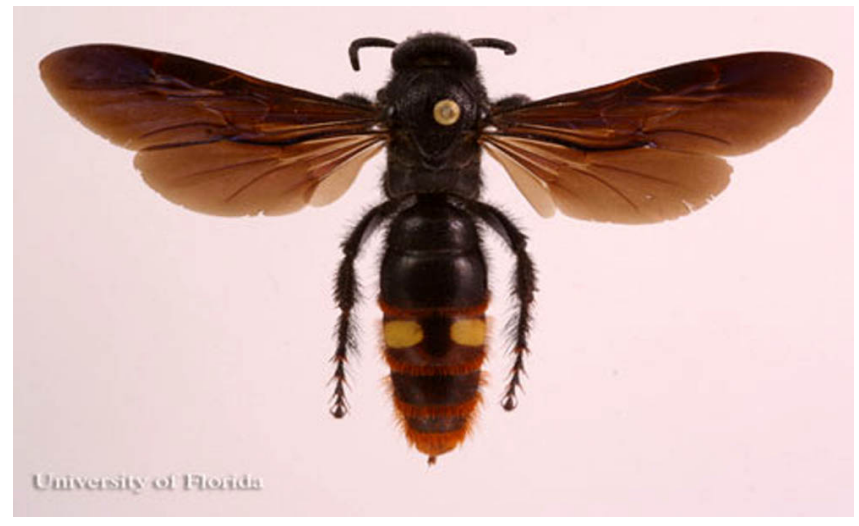

Figure 12. Adult Scolia dubia Say, a scoliid wasp. Credits: Lyle J. Buss, University of Florida

\section{Species in Genus Campsomeris}

There are nine Nearctic species of Campsomeris, of which four occur in Florida. They may be

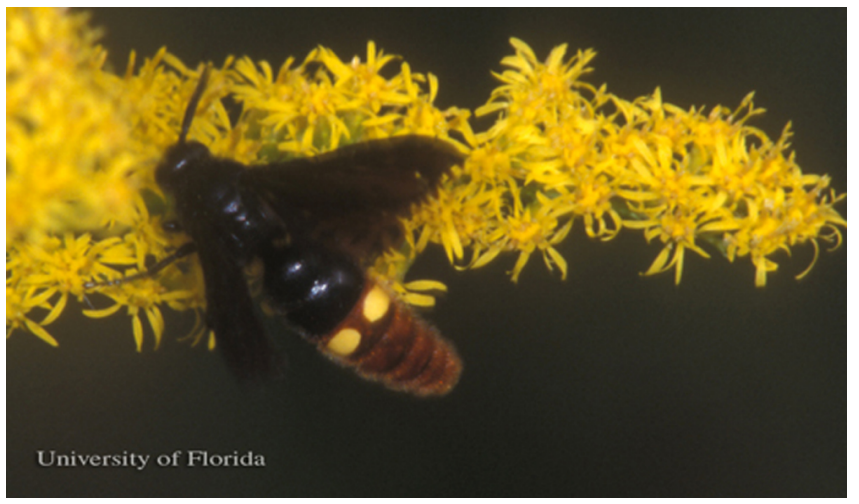

Figure 13. Adult Scolia dubia Say, a scoliid wasp. Credits: Lyle J. Buss, University of Florida

separated by color pattern, but since the sexes differ both in pattern and shape of abdomen, it is necessary to illustrate each sex. Male specimens usually have the black areas of the abdomen with a faint metallic blue sheen. Females have six abdominal segments and males have seven. Some of these wasps are among the largest in Florida.

\section{Campsomeris quadrimaculata (Fabricius)}

Variation: Body length is 15 to $35 \mathrm{~mm}$. Females are easily characterized by the four orange spots which are stable, but the males are quite variable. For this reason I have illustrated the extremes of color variation for males, which vary from segments 2 and 3 with yellow spots, to segments 1 through 4 with yellow bands.

Distribution: This species ranges throughout most of the southeastern United States.

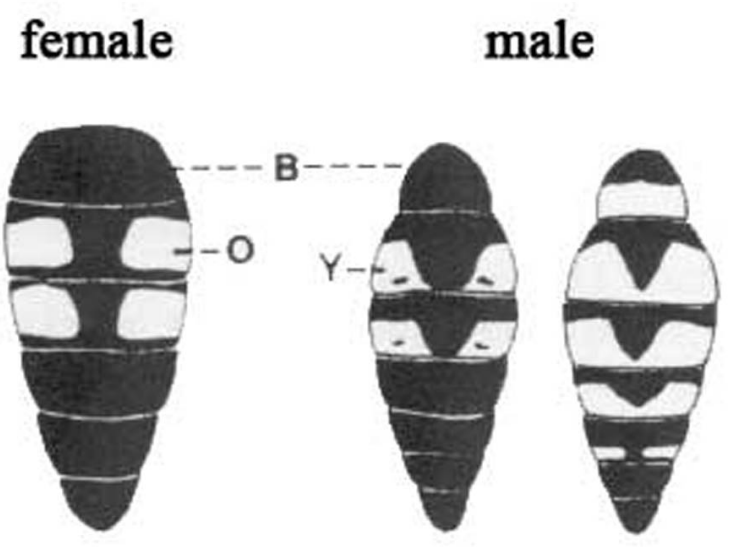

Figure 14. Campsomeris. Credits: Division of Plant Industry 


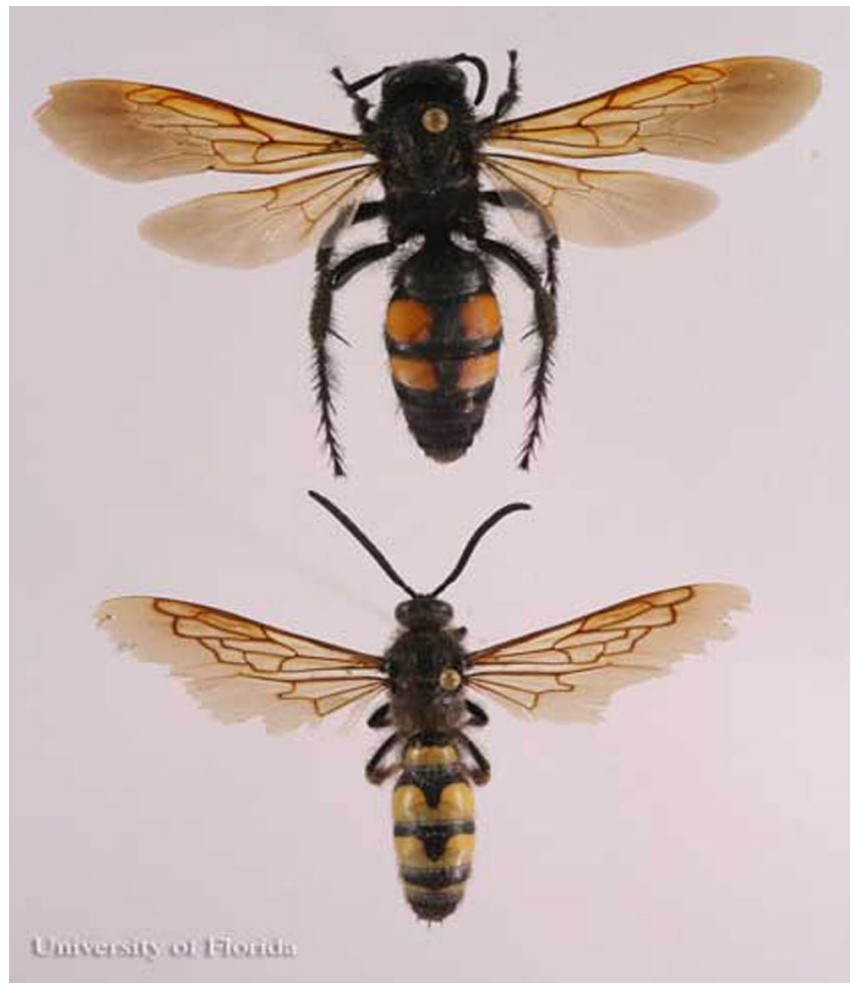

Figure 15. Adult Campsomeris quadrimaculata (Fabricius), scoliid wasps. Female (top), male (bottom). Credits: Lyle J. Buss, University of Florida

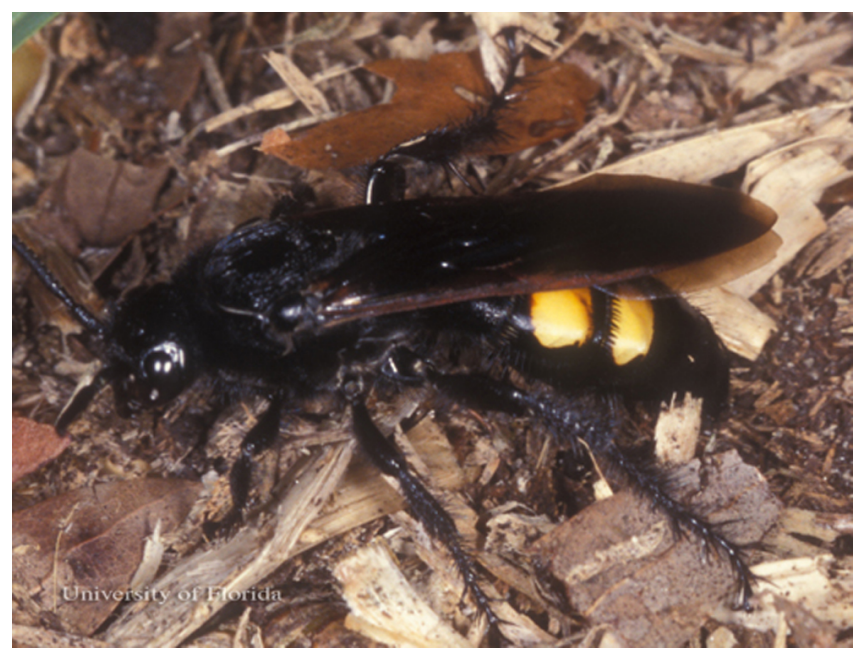

Figure 16. Adult Campsomeris quadrimaculata (Fabricius), a scoliid wasp. Credits: Lyle J. Buss, University of Florida

\section{Campsomeris trifasciata (Saussure)}

Variation: Body length is 10 to $15 \mathrm{~mm}$. Both females and males have stable coloration and pattern.

Distribution: Found in southern Florida and most of the Greater Antilles.

\section{female}

male

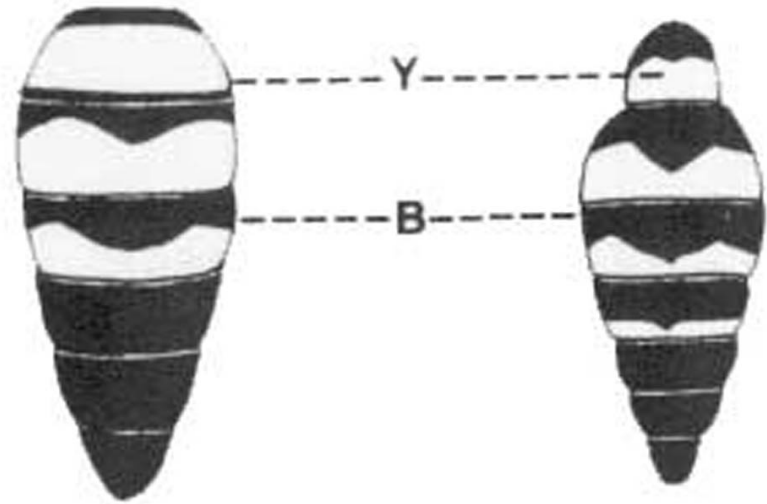

Figure 17. Campsomeris. Credits: Division of Plant Industry

Biology: Bradley (1928) reported that this species laid eggs on larvae of the scarab Phyllophaga portoricensis Smyth (presumably in Puerto Rico).

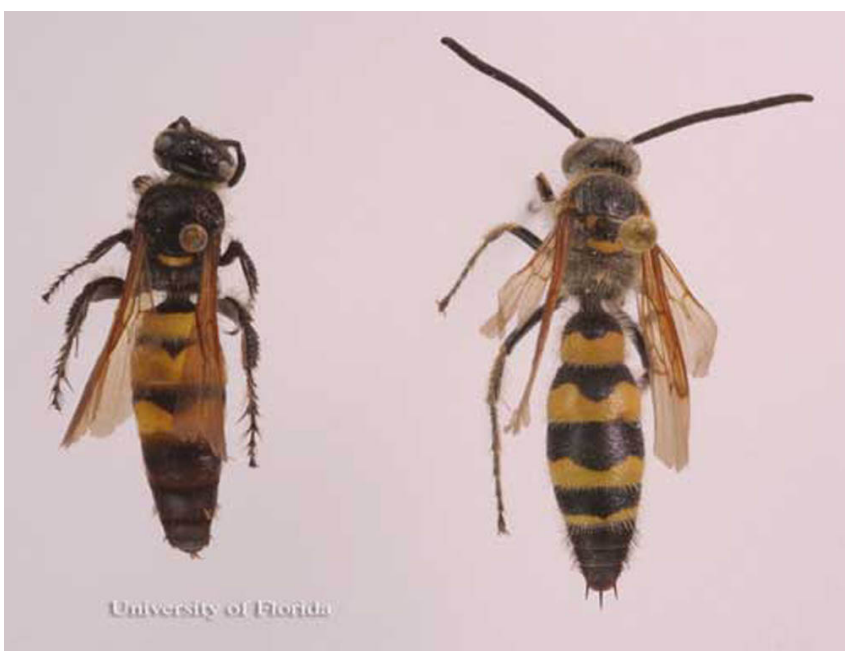

Figure 18. Adult Campsomeris trifasciata (Saussure), scoliid wasps. Female (left), male (right). Credits: Lyle J. Buss, University of Florida

\section{Campsomeris fulvohirta (Cresson)}

Variation: Body length is 15 to $20 \mathrm{~mm}$. This is an uncommon species, and no variation was apparent in the few specimens I have seen.

Distribution: This species is known from southern Florida and Cuba.

Remarks: Males could be confused with those of C. trifasciata. They may be separated, however, by the last three abdominal segments of fulvohirta being orange-brown while those of trifasciata are black. 


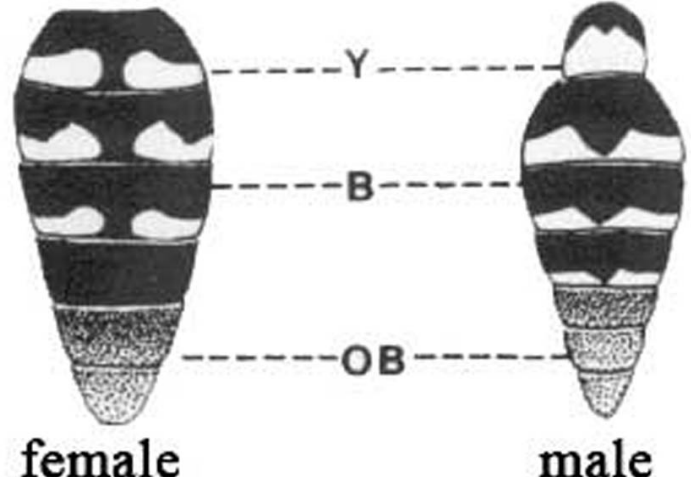

Figure 19. Campsomeris fulvohirta (Cresson). Credits: Division of Plant Industry

Also, fulvohirta has the scutellum with two yellow spots, while trifasciata has a single yellow band.

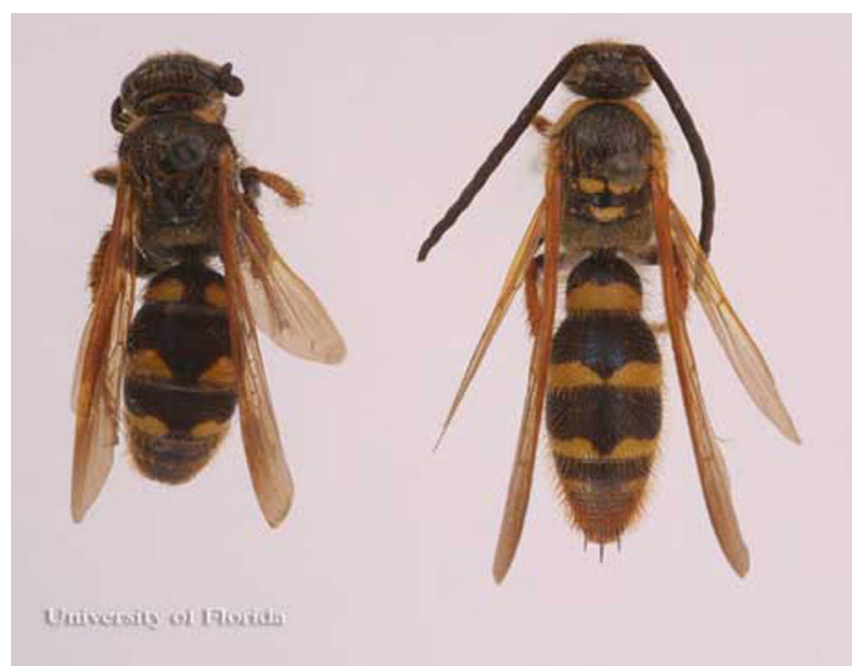

Figure 20. Adult Campsomeris fulvohirta (Cresson), scoliid wasps. Female (left), male (right). Credits: Lyle J. Buss, University of Florida

\section{Campsomeris plumipes fossulana (Fabricius)}

Variation: Body length is 15 to $25 \mathrm{~mm}$. Both sexes have stable color patterns.

Distribution: The species occurs over almost all of the eastern United States, but is divided into three forms (subspecies). The form in Florida, $C . p$. fossulana, occurs throughout the lower southeastern United States.

Biology: Flower visitation records were given by Krombein (1952) for the Florida subspecies, and Kurczewski (1963) reported on the biology of a Midwestern subspecies.

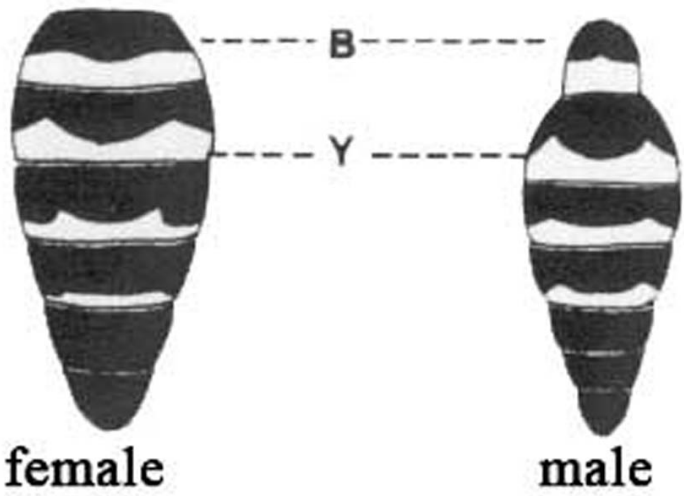

Figure 21. Campsomeris plumipes fossulana (Fabricius). Credits: Division of Plant Industry

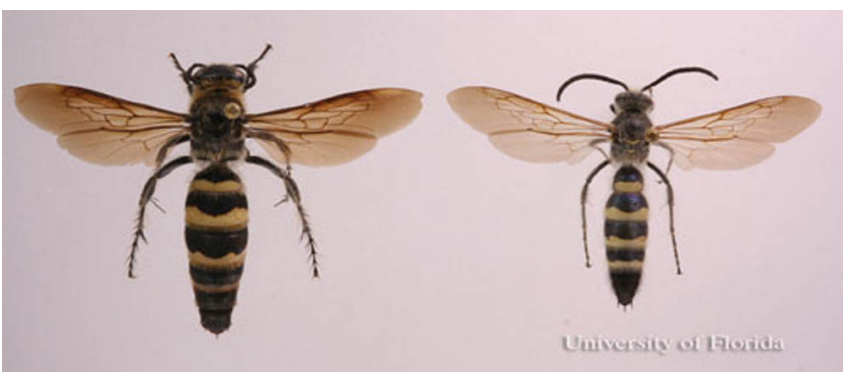

Figure 22. Adult Campsomeris plumipes fossulana (Fabricius), scoliid wasps. Female (left), male (right). Credits: Lyle J. Buss, University of Florida

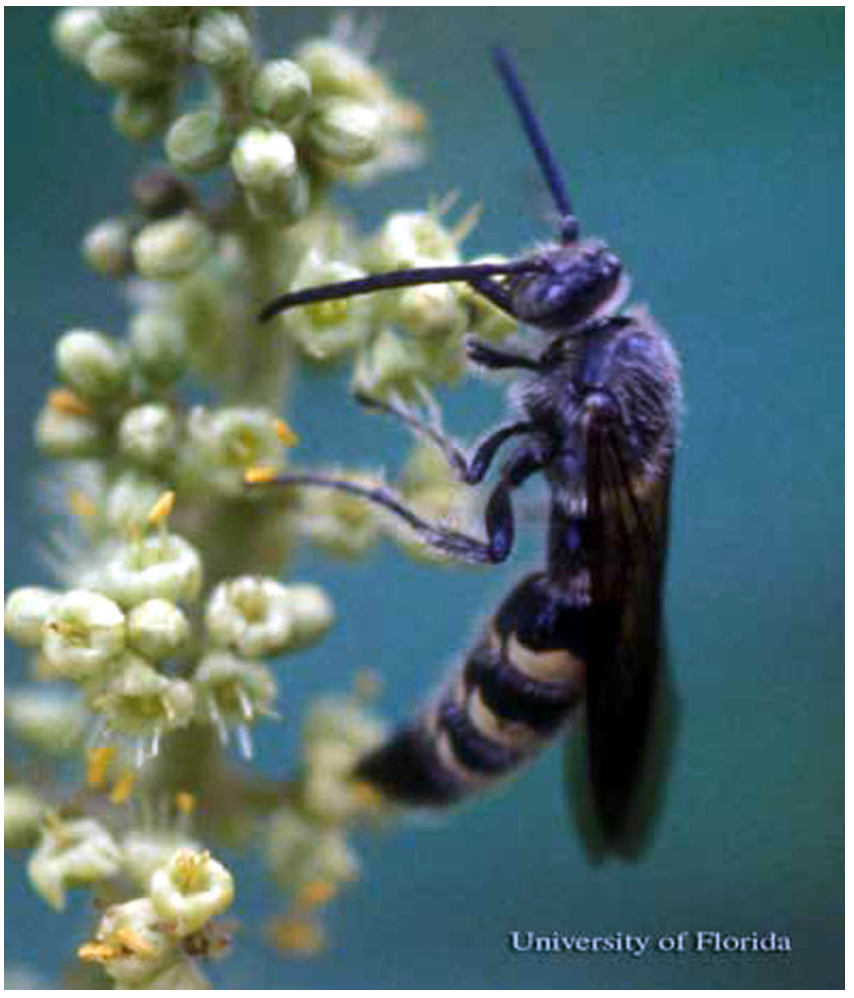

Figure 23. Adult Campsomeris plumipes fossulana (Fabricius), a scoliid wasp. Credits: Lyle J. Buss, University of Florida 


\section{Selected References}

Arnett Jr RH. 2000. American Insects: A Handbook of the Insects of America North of Mexico. CRC Press. Boca Raton. 1003 pp.

Betrem JG. 1972 (1971). The African Campsomerinae. Mon. Nederlandse Ent. Ver. 6: $1-326$.

Bradley JC. 1928. The species of Campsomeris of the Plumipes Group, inhabiting the United States, the Greater Antilles, and the Bahama Islands. Proceedings of the Academy of Sciences of Philadelphia 80: 313-337.

Bradley JC. 1945. The Scoliidae of northern South America, with especial reference to Venezuela. 1. The genus Campsomeris. Boletin de Entomologia Venezolana 4: 1-36.

Brothers DJ. 1975. Phylogeny and classification of the aculeata Hymenoptera, with special reference to Mutillidae. University of Kansas Scientific Bulletin 50: 483-648.

Clausen CP. 1940. Entomophagous Insects. McGraw-Hill Book Co., Inc., New York, N.Y. 688 p.

DeBach P. 1964. Successes, trends and future possibilities. In DeBach P, editor. Biological Control of Insect Pests and Weeds. Chapman and Hall Ltd., London.

Charmoy D. d' Emmerez de. 1922. An attempt to introduce scoliid wasps from Madagascar to Mauritius. Bulletin of Entomological Research 13: 245-254.

Evans HE, Eberhard MJW. 1970. The Wasps. The University of Michigan Press, Ann Arbor. 265 p.

Fleming WE. 1968. Biological control of the Japanese beetle. U.S. Department of Agriculture Technical Bulletin 1383. 78 p.

Iwata K. 1976. Evolution of Instinct. Comparative Ethology of Hymenoptera. Amerind Publishing Co. Pvt. Ltd., New Delhi, India. (Translated from 1972 (1971) Japanese edition by
Smithsonian Institution and National Science Foundation, Technical Translation TT73-52016). 535 p.

Krombein KV. 1948. Liberation of Oriental scolioid wasps in the United States from 1920 to 1946. Annals of the Entomological Society of America 41: 58-62.

Krombein KV. 1951. Scoliidae. In Muesebeck et al., Hymenoptera of America North of Mexico, synoptic catalog. U.S. Department of Agriculture Monograph 2.

Krombein KV. 1952. Biological and taxonomic observations on the wasps in a coastal area of North Carolina. Wasmann Journal of Biology 10: 257-341.

Krombein KV. 1958. Scoliidae. In Krombein et al., Hymenoptera of America North of Mexico, synoptic catalog. U.S. Department of Agriculture Monograph 2, Suppl. 1.

Krombein KV. 1967. Scoliidae. In Krombein et al., Hymenoptera of America North of Mexico, synoptic catalog. U.S. Department of Agriculture Monograph 2, Suppl. 2.

Kurczewski FE. 1963. Biological notes on Campsomeris plumipes confluenta (Say).

Entomological News 74: 21-24.

Malyshev SI. 1968. Genesis of the Hymenoptera and the phases of their evolution. Methuen and Co., Ltd., London. (Translated from 1966 Russian edition by National Lending Library for Science and Technology). 319 p.

Rau P. 1932. The courtship dance and sleeping habits of Scolia dubia. Bulletin of the Brooklyn Entomological Society 27: 59-62.

Rau P, Rau N. 1918. Wasps Studies Afield. Princeton Univ. Press., Princeton, N.J. 372 p.

Spradbery JP. 1973. Wasps. An Account of the Biology and Natural History of Solitary and Social Wasps. University of Washington Press, Seattle. 408 p. 